\title{
Addition of buttermilk powder to yogurt: effects on particle size, microstructure and
}

\section{texture}

\author{
Adlição de leitelho em pó ao iogurte: efeitos no tamanho de partículas, microestrutura e textura \\ Adición de suero de leche en polvo al yogur: efectos sobre el tamaño de partícula, la \\ microestructura y la textura
}

Received: 08/13/2021 | Reviewed: 08/22/2021 | Accept: 08/25/2021 | Published: 08/25/2021

Elisângela Ramieres Gomes

ORCID: https://orcid.org/0000-0002-0010-3945

Federal University of Viçosa, Brazil

E-mail: elisangelaramieres@yahoo.com.br

Mariana Braga de Oliveira

ORCID: https://orcid.org/0000-0002-1794-2198

Federal University of Juiz de Fora, Brazil

E-mail: marianabraga.oliv@gmail.com

Isis Rodrigues Toledo Renhe

ORCID: https://orcid.org/0000-0003-3724-4060 Cândido Tostes Dairy Institute, Brazil

E-mail: isis@epamig.br

Rodrigo Stephani

ORCID: https://orcid.org/0000-0003-0237-8325

Federal University of Juiz de Fora, Brazil

E-mail: rodrigostephani@gmail.com

Antônio Fernandes de Carvalho

ORCID: https://orcid.org/0000-0002-3238-936X

Federal University of Viçosa, Brazil

E-mail: antoniofernandes@ufv.br

Alisson Borges de Souza

ORCID: https://orcid.org/0000-0002-3066-214X

State University of Campinas, Brazil

E-mail: alissonborgesdesouza@hotmail.com

Ítalo Tuler Perrone

ORCID: https://orcid.org/0000-0002-3393-4876

Federal University of Juiz de Fora, Brazil

E-mail: italotulerperrone@gmail.com

Alan Frederick Wolfschoon-Pombo

ORCID: https://orcid.org/0000-0002-8198-7059

Inovaleite, Grupo de Pesquisa Multicêntrico, Brazil

E-mail: awolfschoon@googlemail.com

\begin{abstract}
The addition of buttermilk powder as partial fat replacer in yogurt formulations with constant dry matter was investigated. Three formulations of yogurt were produced containing $0 \%(\mathrm{~T} 1), 1.36 \% \mathrm{w} \cdot \mathrm{w}^{-1}(\mathrm{~T} 2)$ and $3.34 \% \mathrm{w} \cdot \mathrm{w}^{-1}(\mathrm{~T} 3)$ of buttermilk powder in the final product. Particle size and $\mathrm{pH}$ variation were monitored during fermentation; scanning electron microscopy and texture profile analysis were performed in the final product. The control sample showed larger particle size on the day after production and at the end of fermentation, as well as a more compact network microstructure with a smaller average pore size. Compared to the prototypes with added buttermilk the control sample showed greater higher firmness. Buttermilk powder could act as fat replacer for yogurt but favors the formation of a less compacted network microstructure, with large pores, less springiness after 21 days, and less hardness in the two evaluated times ( 21 and 42 days).
\end{abstract}

Keywords: Buttermilk; Particle size; Phospholipids; Fermentation.

\section{Resumo}

A adição de leitelho em pó como substituto parcial da gordura em formulações de iogurte com matéria seca constante foi investigada. Foram produzidas três formulações de iogurte contendo $0 \%(\mathrm{~T} 1), 1,36 \% \mathrm{p} \cdot \mathrm{p}^{-1}$ (T2) e 3,34\% $\mathrm{p} \cdot \mathrm{p}^{-1}$ (T3) de leitelho em pó no produto final. $\mathrm{O}$ tamanho das partículas e a variação do $\mathrm{pH}$ foram monitorados durante a fermentação; microscopia eletrônica de varredura e análise do perfil de textura foram realizadas no produto final. A amostra controle apresentou maior tamanho de partícula no dia seguinte à produção e no final da fermentação, bem como uma microestrutura de rede mais compacta com menor tamanho médio de poro. Em comparação com os 
protótipos com leitelho adicionado, a amostra de controle apresentou maior firmeza. O leitelho em pó pode atuar como substituto da gordura do iogurte, mas favorece a formação de uma microestrutura de rede menos compactada, com poros dilatados, menor elasticidade após 21 dias e menor dureza nos dois tempos avaliados ( 21 e 42 dias).

Palavras-chave: Leitelho; Tamanho da partícula; Fosfolipídios; Fermentação.

\section{Resumen}

Se investigó la adición de suero de leche en polvo como sustituto de grasa parcial en formulaciones de yogur con materia seca constante. Se produjeron tres formulaciones de yogur que contenían $0 \%(\mathrm{~T} 1), 1,36 \% \mathrm{p} \cdot \mathrm{p}^{-1}$ (T2) y 3,34\% p $\mathrm{p}^{-1}$ (T3) de suero de leche en polvo en el producto final. El tamaño de las partículas y la variación del pH se controlaron durante la fermentación; Se realizaron microscopía electrónica de barrido y análisis del perfil de textura en el producto final. La muestra de control mostró un tamaño de partícula más grande el día después de la producción y al final de la fermentación, así como una microestructura de red más compacta con un tamaño de poro promedio más pequeño. En comparación con los prototipos con suero de leche añadido, la muestra de control mostró una mayor firmeza. El suero de leche en polvo podría actuar como sustituto graso del yogur pero favorece la formación de una microestructura de red menos compactada, con poros dilatados, menor elasticidad a los 21 días y menor dureza en los dos tiempos evaluados (21 y 42 días).

Palabras clave: Suero de leche; Tamaño de partícula; Fosfolípidos; Fermentación.

\section{Introduction}

Butter manufacture consists of churning cream with high fat content at high shear rates, destabilizing the oil/water emulsion with subsequent phase separation (Hickey et al., 2017). One phase is rich in triglycerides that coalesce due to their hydrophobic nature, forming grains that are subsequently conjoined to produce butter (> 80\% fat) (Govindasamy-Lucey et al., 2006). The other phase resembling skim milk is called buttermilk and contains the components of the fat globule membrane; the latter is excluded from the lipid matrix during the butter-making process and recovered in the aqueous phase together with most proteins, lactose, and minerals

Buttermilk is rich in several proteins, glycoproteins, and phospholipids that have the potential for functional and nutraceutical applications (Morin et al., 2006). Water-holding and emulsifying capacity stands out among its important functional properties, which means that buttermilk can be used in the production of foods such as dulce de leche, cheese, and yogurt (Le et al., 2011; Morin et al., 2008; Munck et al., 1983; Roesch et al., 2004). Due to its nutraceutical properties, buttermilk is considered a beneficial ingredient for infant formulas, as it is related to many health benefits such as prevention of colon cancer (Dewettinck et al., 2008; Fuller et al., 2013; Spitsberg, 2005; Sprong et al., 2002; Ward et al., 2009).

Buttermilk used as raw material in the food industry undergoes processes such as homogenization, pasteurization, dehydration by evaporation and/or spray drying (Ferreira et al., 1999; Vanderghem et al., 2010). Buttermilk powder can be used as a partial substitute for solids in various products as baked goods and yogurt (Hickey et al., 2018; Scalbert et al., 2005). The evaluation of sensory properties and volatile compounds of whole (fat) yogurt, skimmed yogurt, and skimmed yogurt added with different concentrations of buttermilk showed that buttermilk provided sensory improvements in low-fat yogurts, is therefore recommended as a partial substitute for milk fat in product development (Zhao et al., 2018).

The aim of this work was to evaluate the impact of adding different concentrations of buttermilk powder and water in yogurts (keeping the solids content constant) in the texture profile, particle size, and the microstructure of the yogurt.

\section{Methodology}

The present work was conducted in a partnership between the Milk and Dairy Product laboratory (INOVALEITE) of the Federal University of Viçosa (UFV) and the laboratories of spectroscopy, microstructure and microanalysis of the Spectroscopy and Molecular Structure Nucleus of the Federal University of Juiz de Fora (UFJF). The experiment consisted of yogurts production supplemented with buttermilk and posterior analysis for microstructure characterization. Two independent productions were made $(\mathrm{n}=2)$. 


\subsection{Yogurt production}

Yogurts were prepared from pasteurized whole milk and were standardized to $3.5 \%$ fat $\left(\mathrm{w} \cdot \mathrm{w}^{-1}\right)$. The formulations used to produce yogurts are exposed in Table 1 . The treatments consisted of standardized milk (T1), standardized milk added with $1.36 \% \mathrm{w} \cdot \mathrm{w}^{-1}$ buttermilk (CONFEPAR $®$, Londrina, Brazil) and $8.64 \% \mathrm{w} \cdot \mathrm{w}^{-1}$ of water in the final product (T2) and standardized milk added with $3.34 \% \mathrm{w} \cdot \mathrm{w}^{-1}$ buttermilk and $21.26 \% \mathrm{w} \cdot \mathrm{w}^{-1}$ of water in the final product (T3) (Figure 1). These buttermilk and water concentrations were defined so that the total solids remained constant at $12.5 \% \mathrm{w} \cdot \mathrm{w}^{-1}$. After sample preparation, each treatment (T1, T2, and T3) were heated to $40^{\circ} \mathrm{C}$ and homogenized (APV model 1000-2000, Bydgoszcz, Poland) at $20 \mathrm{MPa}$, in a two-stages homogenizer, whereby p1 $\sim 15 \mathrm{MPa}$ (first stage) and (p2) $\sim \mathrm{MPa}$ (second stage). Afterward, the mixes were heat treated $\left(90{ }^{\circ} \mathrm{C}\right.$ for $5 \mathrm{~min}$ ) in a water bath, then cooled to $42{ }^{\circ} \mathrm{C}$ in an ice bath and $1 \%$ of the starter culture (composed of Streptococcus salivarius subsp. thermophilus and Lactobacillus delbrueckii subsp. Bulgaricus, (Delvo-YogTM, CY-340, DSL, $\mathrm{DSM} \circledast$, Liverpool, Australia) added. The fermentation was monitored until $\mathrm{pH} 4.6 \pm 0.1$ was reached. Then, the yogurt was cooled and the gel was broken with the aid of a plastic rod with circular movements for 30 seconds. The yogurts were placed in $130 \mathrm{~mL}$ packages with approximately $130 \mathrm{~g}$ of the yogurt, and the packages were sealed with aluminum foils and closed with plastic lids and subsequently stored at $4 \pm 1{ }^{\circ} \mathrm{C}$ for 42 days.

Table 1. Yogurt's formulation.

\begin{tabular}{lccc}
\hline & \multicolumn{3}{c}{ Treatments } \\
\hline Ingredients & $\mathbf{T 1}$ & $\mathbf{T 2}$ & $\mathbf{T 3}$ \\
& $\left(\boldsymbol{\%} \mathbf{w}^{\cdot} \mathbf{w}^{-\mathbf{1}}\right)$ & $\left(\boldsymbol{\%} \mathbf{w}^{\cdot} \mathbf{w}^{-\mathbf{1}}\right)$ & $\left(\boldsymbol{\%} \mathbf{w}^{-\mathbf{1}}\right)$ \\
\hline Milk & 100 & 90 & 75.4 \\
Buttermilk & - & 1.36 & 3.34 \\
Water & - & 8.64 & 21.26 \\
\hline
\end{tabular}

$\mathrm{T} 1=$ No added buttermilk; $\mathrm{T} 2=1.36 \%$ buttermilk added; $\mathrm{T} 3=3.34 \%$ buttermilk added. Source: Research data (2021). 
Figure 1. Flowchart of yogurt production.
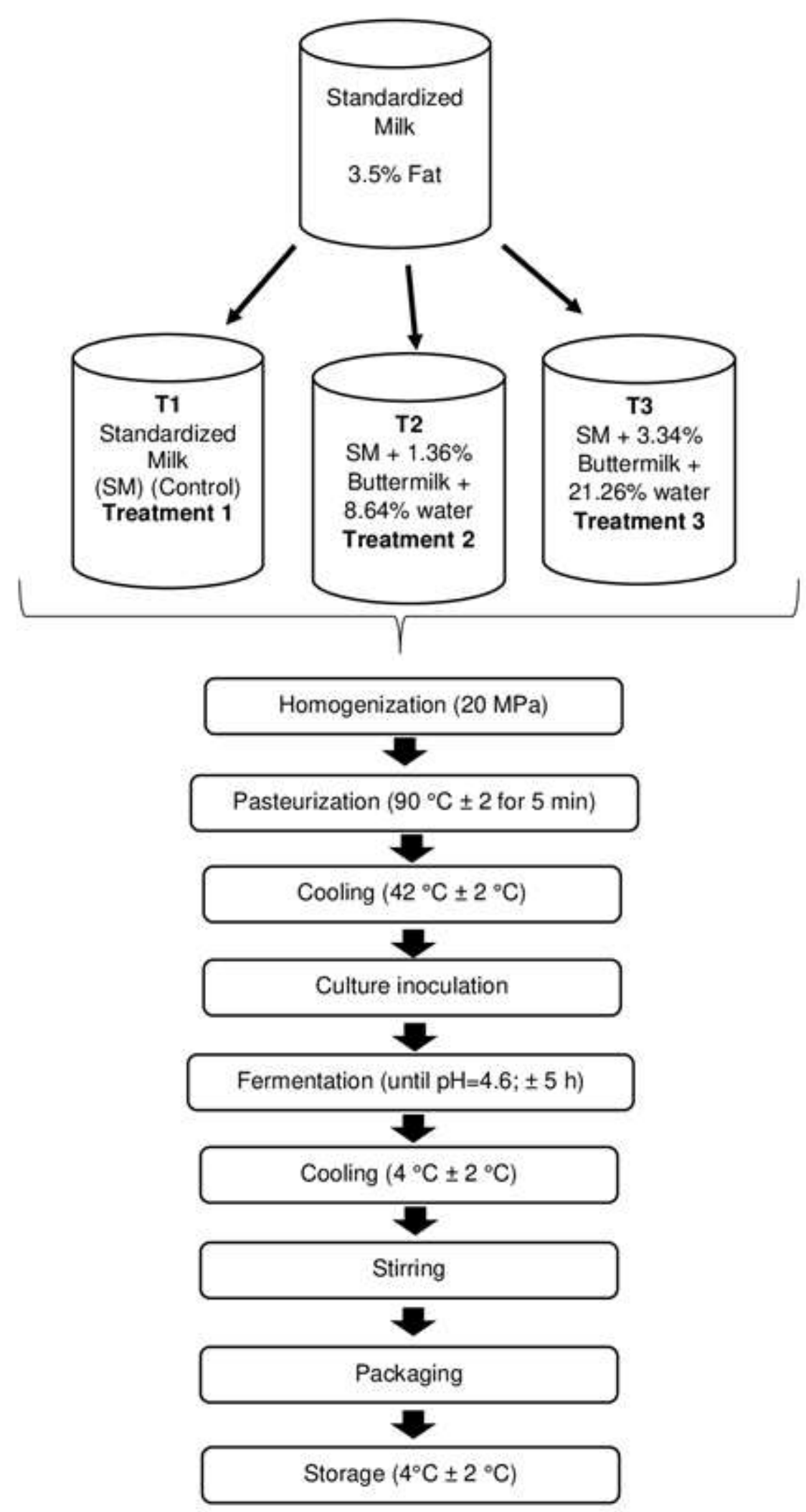

Source: Research data (2021). 


\subsection{Physico-chemical analysis}

Samples T1, T2, and T3 were analyzed for total solids by the standard gravimetric method, total protein by the micro Kjeldahl method, fat by the Gerber (butyrometer) method, ashes by incineration at $550{ }^{\circ} \mathrm{C}$, and lactose by the Fehling reduction method, following to the official methodology described by the Ministry of Agriculture, Livestock and Supply (MAPA) (Brasil, 2017).

\subsection{Fermentation curve}

Beakers with a $1000 \mathrm{~mL}$ capacity received $900 \mathrm{~g}$ of the formulations of each treatment. Fermentation was monitored using a Consort D130 system (Turnhout, Belgium), a multichannel pH meter. An electrode was inserted in each beaker and the $\mathrm{pH}$ was measured every minute during the whole fermentation time until the final $\mathrm{pH}$ of 4.6 with the assistance of a software (Data Acquisition System). Thus, it was possible to monitor the entire fermentation and evaluate the acidification rate and the time required to arrive at a $\mathrm{pH}$ of 4.6 .

\subsection{Scanning electron microscopy}

A thin layer of each yogurt sample was applied individually in a double-sided adhesive carbon tape, mounted on a stub, and then frozen and lyophilized. The microstructures of the yogurt were evaluated by Scanning Electron Microscopy (SEM) (Hitachi TM 3000, Hitachi Ltd., Tokyo, Japan) as described by Mudgil et al. (2018). The images were recorded at different magnifications for better evaluation. The average pore sizes of the images were calculated using Image J 1.47v freeware (National Institutes of Health, USA). The images obtained from the SEM are added in the Image J, the scale is defined after the image is transformed into a black and white binary, so the pores are highlighted, so with particle analysis the average pore size is calculated. Image analyzes were performed in triplicate.

\subsection{Particle size analysis}

Particle size distribution was determined every hour from the dairy culture inoculation until the end of fermentation. This analysis was also carried out a day after the production of the yogurt. The Beckman Coulter LS 13320 laser diffraction analyzer (Beckman Coulter, Miami, FL, USA) coupled to the liquid analysis module (Aqueous liquid module, Beckman Coulter, Miami, FL, USA) was used. In the equipment compartment containing water at $25{ }^{\circ} \mathrm{C}$ standard equipment, the yogurt sample was added until reaching a "Differential Intensity Scattering Polarization (PIDS)" of approximately 45\% (recommendation by the manufacturer of the laser diffraction analyzer). The PIDS comprises three wavelengths $450 \mathrm{~nm}, 600 \mathrm{~nm}$ and $900 \mathrm{~nm}$ that illuminate the sample with polarized light vertically and horizontally. The calculation of the diameters was based on the theory of Mie, using the refractive indices of 1.33 for water 1.57 for protein and 1.47 for fat. The particle size diameter value below those of which $90 \%$ of the particle volume $\left(\mathrm{d}_{90}\right)$ found was used to characterize the formation of the gel. The analyses were performed in duplicate.

\subsection{Texture}

Texture analysis was performed using a texture-meter (Amatek Brookfield CT3, Middleborough, United States). All treatments were analyzed after 21 and 42 days. The yogurt samples were stored in plastic containers with a diameter of $60 \mathrm{~mm}$ and a height of $50 \mathrm{~mm}$. A probe with a diameter of $25 \mathrm{~mm}$ (TA 25/1000) was used and the test was performed at a speed of 1 $\mathrm{mm} \cdot \mathrm{s}^{-1}$ to a depth of $10 \mathrm{~mm}$ and contact force was $2.0 \mathrm{~g}$. Data were collected using the Texture Pro CT V1.4 Build software. Texture Profile Analysis (TPA) was performed to evaluate the parameters firmness (maximum compression force), cohesiveness 
(resistance to removing the sample from the probe when raised), and elasticity (extent and speed at which the sample returns to the original state after deformation force is removed).

\subsection{Statistical analysis}

The experiment followed a completely randomized design (CRD). Two independent yogurt productions were carried out for all treatments. Statistical analyses were performed at 5\% probability using Tukey test and SPSS ${ }^{\circledR}$ statistical software.

\section{Results and Discussion}

\subsection{Proximate composition of formulations}

The composition and mass balance of the bases used for yogurt production are shown in Table 2. The results show that the added amount of buttermilk to the formulations had no significant impact on total solids, protein, and ash content ( $\mathrm{p}>0.05$ ). Total solids were targeted at about $12.5 \%\left(\mathrm{w} \cdot \mathrm{w}^{-1}\right)$. However, Table 2 shows that fat content decreased with an increase in the amount of buttermilk and water added.

Table 2. Composition and mass balance of the base mixtures for yogurt production.

\begin{tabular}{|c|c|c|c|c|c|c|}
\hline Mass balance & Treatment & $\begin{array}{c}\text { Dry matter } \\
\left(\% \mathbf{w}^{\cdot} \mathbf{w}^{-1}\right)\end{array}$ & $\begin{array}{c}\text { Fat } \\
\left(\% \mathbf{w}^{\cdot} \mathbf{w}^{-1}\right)\end{array}$ & $\begin{array}{c}\text { Lactose } \\
\left(\% \mathbf{w} \cdot \mathbf{w}^{-1}\right)\end{array}$ & $\begin{array}{c}\text { Protein } \\
\left(\% \mathbf{w} \cdot \mathbf{w}^{-1}\right)\end{array}$ & $\begin{array}{c}\text { Ash } \\
\left(\% \mathbf{w}^{\cdot} \mathbf{w}^{-1}\right)\end{array}$ \\
\hline \multirow{3}{*}{ Theoretic } & T1 & 12.53 & 3.5 & 4.9 & 3.5 & 1.1 \\
\hline & $\mathbf{T} 2$ & 12.59 & 3.2 & 5.0 & 3.5 & 1.3 \\
\hline & T3 & 12.66 & 2.8 & 5.1 & 3.6 & 1.5 \\
\hline \multirow{3}{*}{ Composition } & T1 & $12.53 \pm 0.25^{\mathrm{a}}$ & $3.5 \pm 0.0^{\mathrm{a}}$ & $4.9 \pm 0.0^{\mathrm{a}}$ & $3.5 \pm 0.0^{\mathrm{a}}$ & $1.1 \pm 0.3^{\mathrm{a}}$ \\
\hline & $\mathbf{T} 2$ & $12.40 \pm 0.26^{\mathrm{a}}$ & $3.3 \pm 0.0^{\mathrm{b}}$ & $5.2 \pm 0.0^{\mathrm{b}}$ & $3.5 \pm 0.1^{\mathrm{a}}$ & $1.4 \pm 0.3^{\mathrm{a}}$ \\
\hline & T3 & $12.83 \pm 0.05^{\mathrm{a}}$ & $3.0 \pm 0.0^{\mathrm{c}}$ & $4.9 \pm 0.1^{\mathrm{a}}$ & $3.6 \pm 0.1^{\mathrm{a}}$ & $0.9 \pm 0.1^{\mathrm{a}}$ \\
\hline
\end{tabular}

Within a column, different superscripts indicate significant differences $(\mathrm{p}<0.05)$. Data are expressed as means \pm standard deviations of triplicate determinations.

$\mathrm{T} 1=$ No added buttermilk; $\mathrm{T} 2=1.36 \%$ buttermilk added; $\mathrm{T} 3=3.34 \%$ buttermilk added.

Source: Research data (2021).

\subsection{Characterization of the fermentation curve and the particle size distribution}

Figure 2 shows the $\mathrm{pH}$ evolution and particle size distribution during the fermentation step. The fermentation curves were similar among treatments, suggesting that buttermilk's addition did not influence the fermentation time. During the first three hours of fermentation, there was a slight variation in the $\mathrm{pH}$ and the size distribution of particles, considering that $\mathrm{d}_{90} \mathrm{had}$ sizes ranging from $1.60 \pm 0.05$ to $1.58 \pm 0.09 \mu \mathrm{m}$ for $\mathrm{T} 1$, from $1.62 \pm 0.10$ to $1.55 \pm 0.22 \mu \mathrm{m}$ for $\mathrm{T} 2$ and $1.47 \pm 0.09$ to $1.44 \pm$ $0.26 \mu \mathrm{m}$ for T3 (Table 3). After 3 hours, at pH below 5.7, the dissociation of the casein micelles begins to occur (Tamime $\&$ Robinson, 2003); this was observed in the increase in particle size, in which $90 \%$ of the particles are smaller than $20.96 \pm 2.99$; $35.54 \pm 7.44$ and $25.36 \pm 4.16 \mu \mathrm{m}$ for treatments $\mathrm{T} 1, \mathrm{~T} 2$ and T3 respectively. With 4 hours of fermentation, T2 presented a larger particle size when compared to T1 and T3 ( $<0.05)$. This may have occurred due to the pH variation among treatments since $\mathrm{T} 2$ had a lower $\mathrm{pH}$ than the other treatments (Table 3). Already at the end of fermentation, treatment T2 with $\mathrm{d}_{90}$ value of 45.55 $\pm 6.43 \mu \mathrm{m}$ showed no statistical difference compared to the $\mathrm{T} 1$ control $\left(\mathrm{d}_{90}=56.22 \pm 4.20 \mu \mathrm{m}\right)$ and $\mathrm{T} 3\left(\mathrm{~d}_{90}=36.23 \pm 6.29 \mu \mathrm{m}\right)$. There was a significant difference between treatments $\mathrm{T} 1$ and T3, with T3 showing the smallest particle size $(\mathrm{p}<0.05)$. 
Figure 2. Relationship between particle size distribution and $\mathrm{pH}$ of the yogurt during fermentation.

$\mathrm{T} 1$

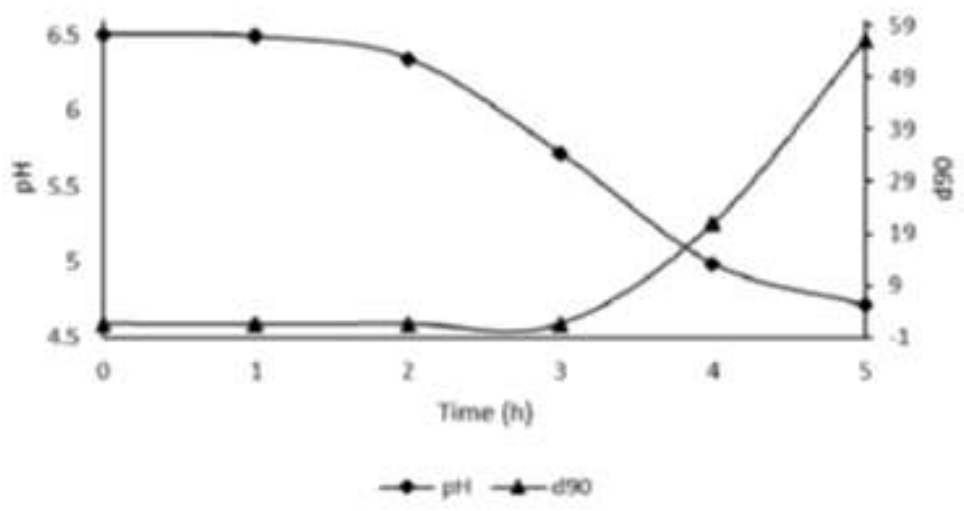

T2

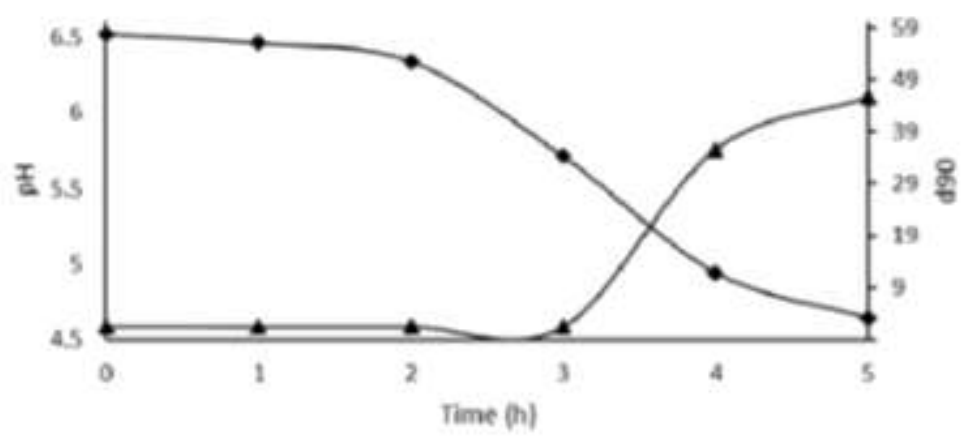

$\rightarrow-9 \mathrm{HH} \rightarrow \mathrm{d}$ d9o

T3

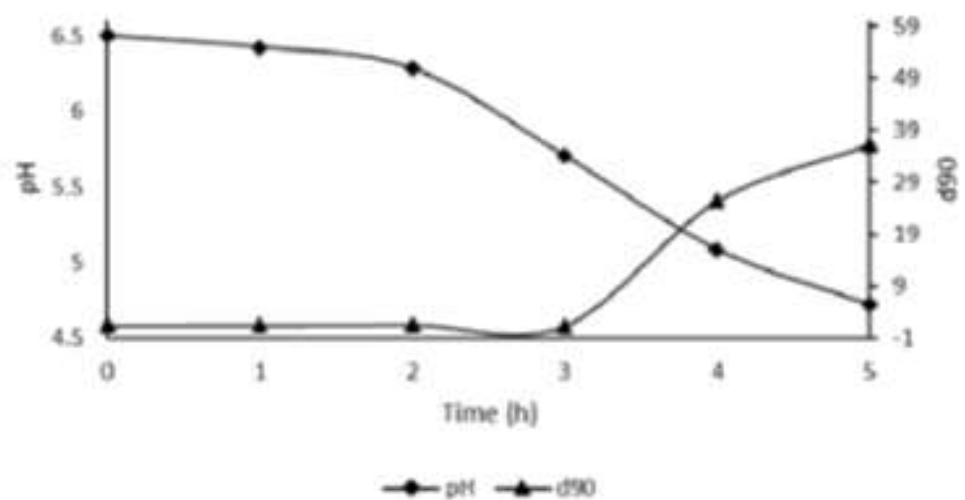

$\mathrm{T} 1=$ No added buttermilk; $\mathrm{T} 2=1.36 \%$ buttermilk added; $\mathrm{T} 3=3.34 \%$ buttermilk added. Source: Research data (2021) 
Table 3. Particle size distribution $\left(\mathrm{d}_{90}\right)$ and $\mathrm{pH}$ during fermentation of yogurt added buttermilk.

\begin{tabular}{|c|c|c|c|c|c|c|}
\hline \multirow{2}{*}{ Time (h) } & \multicolumn{2}{|c|}{ T1 } & \multicolumn{2}{|c|}{$\mathbf{T 2}$} & \multicolumn{2}{|c|}{ T3 } \\
\hline & pH & $\mathrm{d}_{90}(\mu \mathrm{m})$ & pH & $d_{90}(\mu \mathrm{m})$ & pH & $d_{90}(\mu \mathrm{m})$ \\
\hline $\mathbf{0}$ & $6.51 \pm 0.01$ & $1.60 \pm 0.05^{\mathrm{a}}$ & $6.53 \pm 0.04$ & $1.62 \pm 0.10^{\mathrm{a}}$ & $6.50 \pm 0.01$ & $1.47 \pm 0.09^{\mathrm{a}}$ \\
\hline 1 & $6.49 \pm 0.11$ & $1.52 \pm 0.08^{\mathrm{a}}$ & $6.47 \pm 0.04$ & $1.57 \pm 0.01^{\mathrm{a}}$ & $6.43 \pm 0.04$ & $1.59 \pm 0.12^{\mathrm{a}}$ \\
\hline 2 & $6.35 \pm 0.22$ & $1.62 \pm 0.08^{\mathrm{a}}$ & $6.35 \pm 0.11$ & $1.59 \pm 0.07^{\mathrm{a}}$ & $6.29 \pm 0.13$ & $1.65 \pm 0.35^{\mathrm{a}}$ \\
\hline 3 & $5.72 \pm 0.81$ & $1.58 \pm 0.09^{\mathrm{a}}$ & $5.72 \pm 0.66$ & $1.55 \pm 0.22^{\mathrm{a}}$ & $5.71 \pm 0.57$ & $1.44 \pm 0.26^{\mathrm{a}}$ \\
\hline 4 & $4.99 \pm 0.40$ & $20.96 \pm 2.99^{a}$ & $4.95 \pm 0.23$ & $35.54 \pm 7.44^{\mathrm{b}}$ & $5.09 \pm 0.45$ & $25.36 \pm 4.16^{\mathrm{a}}$ \\
\hline 5 & $4.72 \pm 0.16$ & $56.22 \pm 4.20^{\mathrm{a}}$ & $4.65 \pm 0.02$ & $45.55 \pm 6.43^{\mathrm{ab}}$ & $4.72 \pm 0.14$ & $36.23 \pm 6.29^{b c}$ \\
\hline
\end{tabular}

Within a column, different superscripts indicate significant differences $(\mathrm{p}<0.05)$. Data are expressed as means \pm standard deviations of triplicate determinations.

$\mathrm{T} 1=$ No added buttermilk; $\mathrm{T} 2=1.36 \%$ buttermilk added; $\mathrm{T} 3=3.34 \%$ buttermilk added .

Source: Research data (2021).

The development of the gel structure is influenced by heat treatment and fat content (Xu et al., 2008), which might explain the reason why the yogurts with the highest fat content (T1 and T2) presented the largest particle size. The fat globules are bound to the protein after the homogenization and heat treatment, act as pseudoprotein particles and thus are trapped in the protein matrix (Obeid et al., 2020; Ciron et al., 2010), causing the particles to be larger in size. The denaturation of $\beta$ lactoglobulin and $\alpha$-lactalbumin during heat treatment and their association with the fat globule membrane (Ye et al., 2004) also influences the size of the particles, but this alone cannot explain why yogurts without the addition of buttermilk $\left(3.5 \% \mathrm{w} \cdot \mathrm{w}^{-1}\right.$ fat - T1) and yogurt with $1.36 \% \mathrm{w} \cdot \mathrm{w}^{-1}$ buttermilk in the final product $\left(3.3 \% \mathrm{w} \cdot \mathrm{w}^{-1}\right.$ fat - T2) did not differ in the size of its particles in solution, but differed from T3 (with lower fat content $\sim 3.0 \% \mathrm{w} \cdot \mathrm{w}^{-1}$ ).

One factor that can interfere with the denaturation of whey proteins is the presence of phospholipids in the formulation (Kasinos et al., 2014). The addition of phospholipid rich products such as sweet buttermilk powder and residue of cream powder in evaporated milk improves the thermal stability of this product (Kasinos et al., 2014). Phospholipids can modify the secondary structure of whey proteins due to hydrophobic interactions (Kasinos et al., 2014; Kristensen et al., 1997), promoting an increase in heat stability (Kasinos et al., 2014; Saffon et al., 2014). As a greater amount of buttermilk was added to T3, the phospholipids may have interfered in the whey protein denaturation and consequently in the process of gel formation. This can explain why the particle size of treatment T3 was smaller when compared to T1 in the time of $5 \mathrm{~h}$ of fermentation (Table 3).

However, it is interesting to note that the structure of the gel formed showed that the yogurt without buttermilk added (T1) had the largest particle size, while treatments $\mathrm{T} 2$ and $\mathrm{T} 3 \mathrm{had}$ no statistical difference $(\mathrm{p}>0.05)$. These results show that a reduction of $5.7 \%$ (T2) or $14.3 \%$ (T3) of fat in these yogurts in relation to the control did not interfere in the particle size of the gel between treatments $\mathrm{T} 2$ and $\mathrm{T} 3$.

\subsection{The microstructure of the yogurts}

The microstructures of yogurts without (T1) and with (T2 and T3) added buttermilk after 7, 21, and 42 days of storage are shown in Figure 3. After 7 days of storage, the yogurt without added buttermilk (T1) presented a more compact protein network with a medium pore size of $18 \mu \mathrm{m}$, whereas T2 and T3 with the addition of buttermilk, showed larger pores with average sizes of $36 \mu \mathrm{m}$ and $54 \mu \mathrm{m}$ respectively. Romeih, Hamid \& Awad, (2014) also observed in the micrographs a structure more compact, dense with less empty spaces in whole milk buffalo yogurt when compared to fat-free yogurt added $1 \%$ or $2 \%$ powdered buttermilk, and concluded that the fat globules were dispersed in the protein matrix. Another study showed that yogurt made with skimmed milk had larger pores when compared to yogurts added with buttermilk powder, in addition, when the concentrations of $2 \%$ and $4 \%$ buttermilk were added, almost all pores of the gels were filled with phospholipids (Zhao, Feng \& Mao, 2020). After 21 days, the average pore size obtained by SEM was $\mathrm{T} 1=34 \mu \mathrm{m}, \mathrm{T} 2=39 \mu \mathrm{m}$, that is, the difference between 
the average pore size from each treatment was smaller when compared to the 7-day time, generating an attribute of hardness with the same magnitude for these treatments in 21 days. In addition, the average pore size for T3 was $57 \mu \mathrm{m}$, which provided a hardness attribute equal to that of the $\mathrm{T} 2$ treatment. However, after 42 days, $\mathrm{T} 1$ presented an average pore size of $28 \mu \mathrm{m}$, smaller than T2 with $38 \mu \mathrm{m}$ and T3 with $57 \mu \mathrm{m}$, making T2 and T3 less firm than T1 (Table 3). These results indicate that the structure of the protein network, considering the attribute average pore size determined by electron microscopy, is related to the texture of the analyzed yogurts, which is apparently influenced by the levels of fat and phospholipids present.

Figure 3. Microstructure of yogurt added with buttermilk.
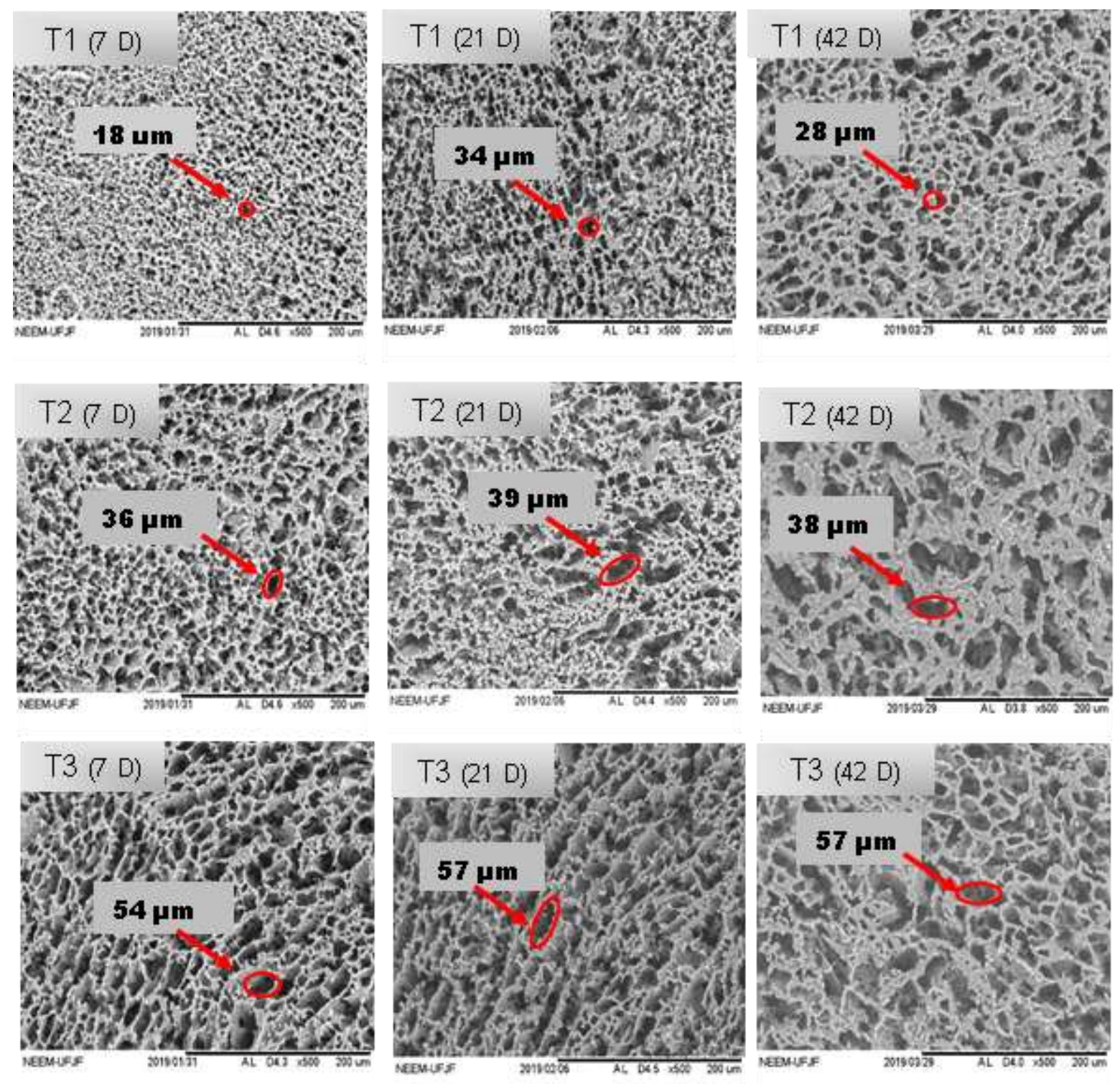

Magnification: 500x. Microscopy after 7, 21, and 42 days of production. $\mathrm{T} 1=$ No added buttermilk; $\mathrm{T} 2=1.36 \%$ buttermilk added; $\mathrm{T} 3=3.34 \%$ buttermilk added. The values presented by the arrows indicate the average pore size. Source: Research data (2021).

It was observed that the average pore sizes of $\mathrm{T} 1$ yogurt showed great variation during the shelf life ( 7 days $=18 \mu \mathrm{m}$; 21 days $=34 \mu \mathrm{m}$ and 42 days $=28 \mu \mathrm{m}$ ), which might be attributed to rearrangements in the protein network. Meanwhile, after 21 and 42 days, treatments T2 $(21$ days $=39 \mu \mathrm{m} ; 42$ days $=38 \mu \mathrm{m})$ and T3 $(21$ days $=57 \mu \mathrm{m} ; 42$ days $=57 \mu \mathrm{m})$ presented the average pore size with little or no variation (Figure 3). The latter findings suggest a role of the added buttermilk in the stabilization of the formed network. 
A more compact protein network structure was observed in the scanning electron microscopy of the yogurt without the addition of buttermilk (T1), which is the treatment with higher fat content (Table 2). This was probably due to the fat globules fusing with the casein, forming aggregates with smaller empty spaces (pores) (Torres et al., 2018). Another factor that may have influenced the microstructure of the yogurt gel is the denaturation of $\beta$-lactoglobulin during pasteurization, which makes it possible to form complexes between this protein and the $\kappa$-casein and the fat globules that are incorporated into the protein network (Obeid et al., 2020; Tamime, 2006). Possible reactions of denatured $\beta$-Lg include interaction with other $\beta$-Lg, interaction with $\kappa$-casein on the surface of casein micelles and interaction with fat globule membrane, which results in an approximate doubling of the amount of fat-bound protein. The lipoprotein particles from the added buttermilk might have enhanced the thickness of the formed secondary membrane after the homogenization treatment, which might be involved in the formation of a different network as in sample T1 and might also account for the differences in the rheological and microstructural properties.

The microstructures of the yogurt gels in this study (Figure 3) presented a branched structure with empty spaces as observed by Vital et al. (2020) in their research with yogurts added with whey protein or soy flour. This branched network is also described as three-dimensional networks of protein chains and aggregation of casein micelles (Aichinger et al., 2003; Jaya, 2009). Further, yogurts with lower fat content (T2 and T3) presented microstructures with larger pores, as reported by Trachoo and Mistry (1998).

\subsection{Texture profile of yogurts}

The results from the texture profile analysis of the yogurt samples are shown in Table 4. There were significant differences $(p>0.05)$ on hardness/firmness between the sample T1, and the samples T2 and T3 with added buttermilk after 21 days of storage. The results showed that the greater the amount of buttermilk added, less hardness was presented by the final products T2 and T3. The decrease in firmness in yogurt with the increase in buttermilk added concentration was also reported by Le et al. (2011) who evaluated the addition of skimmed-milk powder (at concentrations of 12, 11, 10, 9 and $8 \%$ of total solids), buttermilk or fat globule membrane at concentrations of 1, 2, 3 and 4\% of solids in yogurts. Saffon et al. (2013) also reported that the aggregates of buttermilk protein added to yogurt decreased firmness as the level of substitution increased (replacement levels were $0 \%, 20 \%, 40 \%, 60 \%, 80 \%$ or $100 \%$ ). However, Zhao (2020) showed that the addition of 1 or $2 \%$ powdered buttermilk increased the firmness of skimmed yogurt, while the addition of $4 \%$ powdered buttermilk decreased the firmness of skimmed yogurt when compared to skimmed yogurt without added buttermilk.

Table 4. Analysis of yogurt texture after 21 and 42 days of production.

\begin{tabular}{|c|c|c|c|c|c|c|}
\hline \multirow[b]{2}{*}{ Treatment } & \multicolumn{3}{|c|}{ D+21 } & \multicolumn{3}{|c|}{$D+42$} \\
\hline & $\begin{array}{c}\text { Hardness } \\
\text { (g) }\end{array}$ & $\begin{array}{c}\text { Springiness } \\
(\mathbf{m m})\end{array}$ & Cohesiveness & $\begin{array}{c}\text { Hardness } \\
\text { (g) }\end{array}$ & $\begin{array}{c}\text { Springiness } \\
(\mathbf{m m})\end{array}$ & Cohesiveness \\
\hline T1 & $167.00 \pm 1.50^{\mathrm{a}}$ & $9.90 \pm 0.12^{\mathrm{a}}$ & $0,72 \pm 0,00^{\mathrm{a}}$ & $173.00 \pm 1.41^{\mathrm{a}}$ & $9.83 \pm 1.08^{\mathrm{a}}$ & $0,72 \pm 0,09^{a}$ \\
\hline $\mathbf{T 2}$ & $133.00 \pm 8.48^{\mathrm{b}}$ & $8.94 \pm 0.19^{b}$ & $0,73 \pm 0,05^{\mathrm{a}}$ & $127.00 \pm 10.60^{\mathrm{b}}$ & $8.80 \pm 0.31^{\mathrm{a}}$ & $0,74 \pm 0,04^{\mathrm{a}}$ \\
\hline T3 & $98.00 \pm 3.75^{\mathrm{c}}$ & $8.86 \pm 0.12^{\mathrm{b}}$ & $0,77 \pm 0,01^{\mathrm{a}}$ & $110.00 \pm 0.70^{\mathrm{b}}$ & $8.93 \pm 0.24^{\mathrm{a}}$ & $0,79 \pm 0,01^{\mathrm{a}}$ \\
\hline
\end{tabular}

Within a column, different superscripts indicate significant differences $(\mathrm{p}<0.05)$. Data are expressed as means \pm standard deviations of triplicate determinations.

$\mathrm{T} 1=$ No added buttermilk; $\mathrm{T} 2=1.36 \%$ buttermilk added; $\mathrm{T} 3=3.34 \%$ buttermilk added.

Source: Research data (2021). 
The differences in hardness between T1 (always showing the highest hardness values) and T2, T3 were significant ( $p>0.05)$ and remained about the same after 21 and 42 days. A lower firmness of yogurt with less fat content can be attributed to the formation of a protein network composed mainly of chains of casein micelles, since yogurt with higher fat content, casein micelles are extensively fused, since the fat globules act as a promoter of the protein network, as shown by a study by SandovalCastilla et al. (2004), with control yogurt with $2.99 \% \mathrm{w} \cdot \mathrm{w}^{-1}$ fat and reduced yogurt with $1.38 \% \mathrm{w} \cdot \mathrm{w}^{-1}$ fat. Another study revealed that the addition of buttermilk performed poorly during coagulation in cheese making (Morin, Pouliot \& Britten, 2008). These authors suggested that the interaction between fragments of the fat globule membrane and casein resulting from homogenization may prevent the formation of the gel and create a weak clot. These data reinforce the results obtained in the present study, in which yogurts added with buttermilk presented less firmness (T2 and T3) when compared to yogurt without added buttermilk (T1).

Yogurts with a smooth consistency were considered closer to ideal when compared to yogurts with a firmer consistency, and the information contained in the labels influenced the decision of consumers (Ogliare \& Novelho, 2021). A fermented product with added buttermilk and whey had good acceptance with a high purchase intention (Pereira et al., 2021). Therefore, the yogurts added with buttermilk produced in the present study may present a good sensory evaluation by consumers, mainly because this product has a claim to reduce fat and bring health benefits due to the addition of buttermilk.

Moreover, a larger pore size of the T2 and T3 treatments may explain changes in the structure of the yogurt added with buttermilk, which impacts on firmness of the product. These results suggest that the amount of buttermilk added to the yogurt in order to standardize the total solids, while the fat content was diminished, was not enough to form a gel with a stronger and similar structure as the sample T1 without added buttermilk, which consequently impacted the texture of the yogurt. However, this also suggests that formulation can be a way to modify the structure of acidified, fat-reduced products such as yogurt.

Other texture parameters evaluated were springiness, which can be defined as how much a material can be deformed before breaking, and cohesiveness, which is the material's ability to return to its initial shape after being compressed (Mudgil, Barak \& Khatkar, 2017). After 21 days, the springiness of yogurt without the addition of buttermilk (T1) was greater than the other treatments (T2 and T3) and after 42 days there was no significant difference between treatments. It is worth mentioning that cohesiveness showed no significant difference between treatments at any of the evaluated times. A summary of the main results of the experiment is presented in Table 5. 
Research, Society and Development, v. 10, n. 11, e154101119404, 2021

(CC BY 4.0) | ISSN 2525-3409 | DOI: http://dx.doi.org/10.33448/rsd-v10i11.19404

Table 5. The main results of fermentation, average pore size and hardness of the yogurts produced with different concentrations of fat levels and added buttermilk.

$\begin{array}{llll}\text { Fermentation } & \text { D+7 } & \text { D+21 } & \text { D+42 }\end{array}$

\section{Treatment}

\begin{tabular}{|c|c|c|c|c|c|c|c|}
\hline $\begin{array}{l}\text { Time } \\
\text { (h) }\end{array}$ & $p H$ & $\begin{array}{l}\text { Particle size in solution } \\
\qquad d_{90}(\mu \mathrm{m})\end{array}$ & $\begin{array}{c}\text { Average pore } \\
\text { size }(\mu \mathrm{m})\end{array}$ & $\begin{array}{c}\text { Average pore size } \\
(\mu \mathrm{m})\end{array}$ & $\begin{array}{l}\text { Hardness } \\
\qquad(g)\end{array}$ & $\begin{array}{c}\text { Average pore size } \\
(\mu \mathrm{m})\end{array}$ & $\begin{array}{c}\text { Hardness } \\
\quad(g)\end{array}$ \\
\hline
\end{tabular}

After $4 \mathrm{~h} \quad$ After $5 \mathrm{~h}$

\begin{tabular}{|c|c|c|c|c|c|c|c|c|c|c|c|}
\hline $0 \%$ & $3.5 \%$ Fat & & 5 & 4.7 & $20.96^{\mathrm{b}}$ & $56.23^{a}$ & 18 & 34 & $167^{\mathrm{a}}$ & 28 & $173^{\mathrm{a}}$ \\
\hline$+13 \%$ & $3.3 \%$ Fat & $-5.7 \%$ & 5 & 4.6 & $35.54^{\mathrm{a}}$ & $45.55^{\mathrm{ab}}$ & 36 & 39 & $127^{\mathrm{ab}}$ & 38 & $127^{\mathrm{b}}$ \\
\hline$+334 \%$ & $3.0 \%$ Fat & $-14.3 \%$ & 5 & 4.7 & $25.36^{\mathrm{b}}$ & $36.23^{\mathrm{b}}$ & 54 & 57 & $98^{\mathrm{b}}$ & 57 & $110^{\mathrm{b}}$ \\
\hline
\end{tabular}

Within a column, different superscripts indicate significant differences $(p<0.05)$.

Blue arrow indicates percentage $\left(\mathrm{w} \cdot \mathrm{w}^{-1}\right)$ of buttermilk in the yogurt.

Green arrow indicates fat reduction.

Source: Research data (2021). 


\section{Conclusion}

Buttermilk was added to yogurt formulations in a way to not interfere with the total solids content (12.5\%). Consequently, the fermentation time was not affected by the addition of buttermilk in the yogurt nor the particle size during the first hours of fermentation. However, at the end of the fermentation, the yogurt with no buttermilk added (T1) presented the largest particle size, and the yogurt with $3.34 \% \mathrm{w} \cdot \mathrm{w}^{-1}$ of buttermilk added (T3) presented the smallest particle size. The products had different fat content in their composition, which affected the structure. Buttermilk can be used as a fat replacer to produce fermented dairy products with reduced fat content, without affecting the fermentation time, but affecting the particle size distribution and network pore size. However, it leads to the formation of a less compacted network microstructure, less springiness after 21 days and less hardness after 21 and 42 days. Further experiments focused on how much milk fat can be replaced by the fat contributed by the phospholipids from buttermilk, are suggested, especially considering the variables total solids and fat content and sensory evaluation.

\section{Acknowledgments}

Capes (001), CNPq, Fapemig and DSM Nutraceutical Products Brazil.

\section{References}

Aichinger, P. A., Miche, M., Servais, C., Dillmann, M. L., Rouvet, M., D’Amico, N., Zink, R., Klostermeyer, H. \& Horne, D. S. (2003). Fermentation of a skim milk concentrate ith Streptococcus thermophilus and chymosin: Structure, viscoelasticity and syneresis of gels. Colloids and Surfaces B: Biointerfaces, 31(14), 243-255. 10.1016/S0927-7765(03)00144-9

Brasil, (2017) Ministério da Agricultura, Pecuária e Abastecimento Secretaria de Defesa Agropecuária. Ministério da Agricultura, Pecuária e Abastecimento, Brasília.

Ciron, C. I. E., Gee, V. L., Kelly, A. L. \& Auty, M. A. E. (2010). Comparison of the effects of high-pressure microfluidization and conventional homogenization of milk on particle size, water retention and texture of non-fat and low-fat yoghurts. International Dairy Journal, 20(5), 314-320. 10.1016/j.idairyj.2009.11.018

Dewettinck, K., Rombaut, R., Thienpont, N., Le, T. T., Messens, K. \& Van, C. J. (2008). Nutritional and technological aspects of milk fat globule membrane material. International Dairy Journal, 18 (5), 436-457. 10.1016/j.idairyj.2007.10.014

Ferreira, D., Van Rensburg, H., Malan, E., Coetzee, J. \& Nel, R. J. J. (1999). Recent Advances in the Chemistry of Proanthocyanidins. In: Phytochemicals in Human Health Protection, Nutrition, and Plant Defense. Boston: Springer.

Fuller, K. L., Kuhlenschmidt, T. B., Kuhlenschmidt, M. S., Jiménez-Flores, R. \& Donovan, S. M. (2013). Milk fat globule membrane isolated from buttermilk or whey cream and their lipid components inhibit infectivity of rotavirus in vitro. Journal of Dairy Science, 96(6), 3488-3497. 10.3168/jds.2012-6122

Govindasamy-Lucey, S., Lin, T., Jaeggi, J. J., Johnson, M. E. \& Lucey, J. A. (2006). Influence of Condensed Sweet Cream Buttermilk on the Manufacture, Yield, and Functionality of Pizza Cheese. Journal of Dairy Science, 89(2), 454-467. 10.3168/jds.S0022-0302(06)72109-9

Hickey, C. D., Diehl, B. W. K., Nuzzo, M., Millqvist-Feurby, A., Wilkinson, M. G. \& Sheehan, J. J. (2017). Influence of buttermilk powder or buttermilk addition on phospholipid content, chemical and bio-chemical composition and bacterial viability in Cheddar style-cheese. Food Research International, 102, 748-758. 10.1016/j.foodres.2017.09.067

Hickey, C. D., O'Sullivan, M. G., Davis, J., Scholz, D., Kilcawley, K. N., Wilkinson, M. G. \& Sheehan, J. J. (2018). The effect of buttermilk or buttermilk powder addition on functionality, textural, sensory and volatile characteristics of Cheddar-style cheese. Food Research International, 103, $468-477$.

10.1016/j.foodres.2017.09.081

Jaya, S., (2009). Microstructure analysis of dried yogurt: Effect of different drying methods. International Journal of Food Properties, 12 (3), $469-481$. $10.1080 / 1094291070177207$

Kasinos, M., Tran Le, T. \& Van der, M. P. (2014). Improved heat stability of recombined evaporated milk emulsions upon addition of phospholipid enriched dairy by-products. Food Hydrocolloids, 34, 112-118. 10.1016/j.foodhyd.2012.11.030

Kristensen, A., Nylander, T., Paulsson, M. \& Carlsson, A. (1997). Calorimetric studies of interactions between $\beta$-lactoglobulin and phospholipids in solutions. International Dairy Journal, 7(1), 87-92. 10.1016/S0958-6946(96)00038-6

Le, T. T., Van Camp, J., Pascual, P. A. L., Meesen, G., Thienpont, N., Messens, K. \& Dewettinck, K. (2011). Physical properties and microstructure of yoghurt enriched with milk fat globule membrane material. International Dairy Journal, 21(10), 798-805. 10.1016/j.idairyj.2011.04.015

Lucey, J. A., (2002) Formation and Physical Properties of Milk Protein Gels. Journal of Dairy Science, 85(2), 281-294. 10.3168/jds.S0022-0302(02)74078-2 
Morin, P., Pouliot, Y. \& Britten, M. (2008). Effect of Buttermilk Made from Creams with Different Heat Treatment Histories on Properties of Rennet Gels and Model Cheeses. Journal of Dairy Science, 91(3), 871-882. 10.3168/jds.2007-0658

Morin, P., Pouliot, Y. \& Jiménez-Flores, R. (2006). A comparative study of the fractionation of regular buttermilk and whey buttermilk by microfiltration. Journal of Food Engineering, 77(3), 521-528. 10.1016/j.jfoodeng.2005.06.065

Mudgil, P., Jumah, B., Ahmad, M., Hamed, F. \& Maqsood, S. (2018). Rheological, micro-structural and sensorial properties of camel milk yogurt as influenced by gelatin. LWT - Food Science and Technology, 98, 646-653. 10.1016/j.lwt.2018.09.008

Mudgil, D., Barak, S. \& Khatkar, B. S. (2017). Texture profile analysis of yogurt as influenced by partially hydrolyzed guar gum and process variables. Journal Food Science Technology, 54(12), 3810-3817 10.1007 / s13197-017-2779-1

Munck, A. V., Wolfschoon-Pombo, A. F. \& Neves, R. S. (1983). Dulce de Suero de Mantequilla. Industrias Lacteas, $34,22-26$.

Obeid, S., Guyomarc'h, F., Tanguy, G., Leconte, N., Rousseau, F., Dolivet, A., Leduc, A. Wu, X., Couty, C., Jan, G., Gaucheron \& F., Lopez, C. (2020). The adhsion of homogenized fat globules to proteins is increased by milk heat treatment and acidic pH: Quantitative insights provides by AFM force spectroscopy. Food Research International, 129, 1-13. 10.1016/j.foodres.2019.108847

Ogliari, R. \& Novello, D. (2021). Avaliação de iogurte de coco baseado na perspectiva do consumidor: influência das informações do produto sobre o perfil sensorial. Research, Society and Development, 10(2), 1-12. 10.33448/rsd-v10i2.12582

Pereira, A. C., Jardim, F. B. B. \& Jerônimo, M. (2021). Development of pineapple and wine flavored fermented dairy product. Research, Society and Development, 10(7), 1-13. 10.33448/rsd-v10i7.16522

Roesch, R. R., Rincon, A. \& Corredig, M. (2004). Emulsifying Properties of Fractions Prepared from Commercial Buttermilk by Microfiltration. Journal of Dairy Science, 87(12), 4080-4087. 10.3168/jds.S0022-0302(04)73550-X

Romeih, E. A., Hamid, A. M. \& Awad, A. A. (2014). The addition of buttermilk power and transglutaminase improves textural and organoleptic properties of fat-free buffalo yogurt. Dairy Science \& Technology, 94(3), 297-309. 10.1007 / s13594-014-0163-8

Sandoval-Castilla, O., Lobato-Calleros, C. \& Aguirre-Mandujano, E., Verno-Carter, E.J. (2004). Microstructure and texture of yogurt as influenced by fat replacers. International Dairy Journal, 14(2), 151-159. 10.1016/S0958-6946(03)00166-3

Saffon, M., Jiménez-Flores, R., Britten, M. \& Pouliot, Y. (2014). On the use of buttermilk components as aggregation nuclei during the heat-induced denaturation of whey proteins. Journal of Food Engineering, 132, 21-28. 10.1016 / j.jfoodeng.2014.02.001

Saffon, M., Richard, V., Jiménez-Flores, R., Gauthier, S. F., Britten, M., Pouliot, Y. (2013). Behavior of Heat-Denatured Whey:Buttermilk Protein Aggregates during the Yogurt-Marking Process and Their Influence on Set-Type Yogurt Properties. Foods, 2(4), 444-459 10.3390 / foods2040444

Scalbert, A., Manach, C., Morand, C., Rémésy, C. \& Jiménez, L. (2005). Dietary Polyphenols and the Prevention of Diseases. Critical Reviews in Food Science and Nutrition, 45(4), 287-306. 10.1080 / 1040869059096

Spitsberg, V. L., (2005) Invited Review: Bovine Milk Fat Globule Membrane as a Potential Nutraceutical. Journal of Dairy Science, 88(7), 2289-2294 $10.3168 /$ jds.S0022-0302(05)72906-4

Sprong, R., Hulstein, M. F. \& Van der Meer, R. (2002). Bovine milk fat components inhibit food-borne pathogens. International Dairy Journal, 12(1-3), 209215. 10.1016/S0958-6946(01)00139-X

Tamime, A. Y., (2006). Fermented milks Oxford:. Blackwell Science/SDT:.

Tamime, A. Y. \& Robinson, R. K. (2003). Yoghurt Science and Technology (3th ed).

Torres, I. C., Amigo, J. M., Knudsen, J. C., Tolkach, A., Mikkelsen, B. O. \& Ipsen, R. (2018). Rheology and microstructure of low-fat yoghurt produced with whey protein microparticles as fat replacer. International Dairy Journal, 81, 62-71. 10.1016/j.idairyj.2018.01.004

Trachoo, N. \& Mistry, V. V. (1998). Application of Ultrafiltered Sweet Buttermilk and Sweet Buttermilk Powder in the Manufacture of Nonfat and Low Fat Yogurts. Journal of Dairy Science, 81(12), 3163-3171. 10.3168/jds.S0022-0302(98)75882-5

Vanderghem, C., Bodson, P., Danthine, S., Paquot, M., Deroanne, C. \& Blecker, C. (2010). Milk fat globule membrane and buttermilks: from composition to valorization Biotechnol. Biotechonology, Agronomy, Society and Environment, 14(3), 485-500. Registration number: 20103309796

Vital, A. C. P., Itoda, C., Hokazono, T. Y., Crepaldi, Y. S., Saraiva, B. R., Rosa, C. I. L. F. \& Pintro, P. T. M. (2020). Use of soy as a source of protein in lowfat yogurt production: microbiological, functional and rheological properties. Research, Society and Development, 9(11), 1-21. 10.33448/rsd-v9i11.9472

Ward, R. E., German, J. B. \& Corredig, M. (2009). Composition, Applications, Fractionation, Technological and Nutritional Significance of Milk Fat Globule Membrane Material. In: Advanced Dairy Chemistry, Springer.

Xu, Z-M., Emmanouelidou, D. G., Raphaelides, S. N. \& Antoniou, K. D. (2008). Effects of heating temperature and fat content on the structure development of set yogurt. Journal of Food Engineering, 85(4), 590-597. 10.1016/j.jfoodeng.2007.08.021

Ye, A., Singh, H., James, Oldfield, D. \& Anema, S. (2004). Kinetics of heat-induced association of $\beta$-lactoglobulin and $\alpha$-lactalbumin with milk fat globule membrane in whole milk. International Dairy Journal, 14(5), 389-398. 10.1016 / j.idairyj.2003.09.004

Zhao, L., Feng, R., Ren, F. \& Mao, X. (2018). Addition of buttermilk improves the flavor and volatile compound profiles of low-fat yogurt. LWT - Food Science and Technology, 98, 9-17. 10.1016/j.lwt.2018.08.029 
Research, Society and Development, v. 10, n. 11, e154101119404, 2021

(CC BY 4.0) | ISSN 2525-3409 | DOI: http://dx.doi.org/10.33448/rsd-v10i11.19404

Zhao, L., Feng, R., \& Mao, X. (2020). Addtion of buttermilk power improved th rheological and storage properties of low-fat yogurt. Food Science \& Nutrition, 8(7), 3061-3069. 10.1002/fsn3.1373 